\title{
EFIKASI EKSTRAK DAUN JARAK PAGAR (Jatropha curcas L.) SEBAGAI PESTISIDA NABATI UNTUK MENGENDALIKAN LALAT BUAH (Bactrocera dorsalis H.) PADA CABAI (Capsicum annuum L.)
}

\section{THE EFFICACY OF JATROPHA LEAF EXTRACT (Jatropha curcas L.) AS BIOPESTICIDE TO CONTROL FRUIT FLIES (Bactrocera dorsalis H.) ON CHILI (Capsicum annuum L.)}

\author{
Ida Hodiyah, Elya Hartini, Novi Rahmawati \\ Program Studi Agroteknologi Fakultas Pertanian Universitas Siliwangi \\ Korespondensi : hodiyah21@gmail.com hartinielya@gmail.com
}

\begin{abstract}
ABSTRAK
Produksi cabai (Capsicum annuum L.) masih rendah dan belum memenuhi kebutuhan nasional, salah satu penyebabnya adalah serangan lalat buah (Bactrocera dorsalis $\mathrm{H}$.) yang menyebabkan kerugian mencapai $70 \%$. Perlu adanya pengendalian yang efektif, efisien dan ramah lingkungan yaitu dengan menggunakan pestisida nabati. Jarak pagar (Jatropha curcas L.) merupakan salah satu tanaman penghasil pestisida nabati, yang memiliki beragam kandungan senyawa aktif untuk mengendalikan hama. Tujuan penelitian ini adalah untuk mengetahui konsentrasi ekstrak daun jarak pagar yang tepat untuk mengendalikan lalat buah pada cabai.. Penelitian ini menggunakan metode percobaan Rancangan Acak Lengkap (RAL) yang terdiri dari 4 perlakuan dan diulang sebanyak 6 kali, konsentrasi ekstrak daun jarak pagar yang digunakan adalah $0 \% ; 0,04 \% ; 0,08 \%$ dan $0,16 \%$. Hasil penelitian menunjukkan bahwa tidak terdapat konsentrasi ekstrak daun jarak pagar yang efektif untuk mengendalikan lalat buah pada cabai. Hasil analisis GC-MS ekstrak daun jarak pagar dengan menggunakan pelarut metanol, etil asetat dan $n$-heksan menunjukkan bahwa kandungan terbesar senyawa phytol yang diduga berfungsi sebagai repellent, terdapat pada ekstrak daun jarak pagar dengan pelarut etil asetat yaitu sebanyak $21,89 \%$.
\end{abstract}

Kata kunci : Cabai, Lalat buah, Pestisida nabati, Jarak pagar

\begin{abstract}
Chili (Capsicum annuum L.) production is still low and does not meet national needs, one of the causes is fruit fly attacks. The losses attacked by fruit flies (Bactrocera dorsalis H.) estimed reached $70 \%$. It is necessary to find an effective, efficient and environmentally friendly to control this pest by biopesticide. Jatropha (Jatropha curcas L.) is one of the plants producing biopesticide, which has a variety of active compounds to control pests. The purpose of this study was to determine the concentration of jatropha leaf extract which is appropriate for controlling fruit flies on chili. The study was conducted from June 2019 to August 2019 at Siliwangi University Tasikmalaya and Balai Besar Peramalan Organisme Pengganggu Tumbuhan (BBPOPT) Karawang. This study used a completely randomized design (CRD) experimental method that consists of 4 treatments and repeated 6 times, the jatropha leaf extract concentrations used for measurement were $0 \% ; 0,04 \% ; 0,08 \%$; and $0,16 \%$. The result showed that was no proper concentration of Jatropha leaf extract to control fruit flies on chili. GC-MS analysis result of jatropha leaf extract using methanol, ethyl acetate and n-hexane solvents showed that the largest content of phytol compounds that suspected as repellent was found in jatropha leaf extract with ethyl acetate solvent, amounting to $21,89 \%$.
\end{abstract}

Keywords : Chili, Fruit flies, Biopesticide, Jatropha. 


\section{PENDAHULUAN}

Cabai (Capsicum annuum L.) merupakan salah satu komoditas sayuran penting yang bernilai ekonomis tinggi. Tanaman cabai cocok dibudidayakan di Indonesia, serta memiliki potensi yang tinggi untuk dikembangkan dikarenakan tanaman cabai dapat berproduksi dan tumbuh baik di dataran rendah maupun dataran tinggi (BBPPTP, 2008). Setiap tahun permintaan cabai terus meningkat seiring dengan meningkatnya kebutuhan manusia. Namun, hingga saat ini produksi cabai di Indonesia belum mampu mencukupi kebutuhan cabai nasional.

Rendahnya produksi cabai disebabkan oleh berbagai faktor, salah satunya akibat serangan hama di pertanaman. Lalat buah (Bactrocera dorsalis H.) merupakan salah satu hama penting yang menyerang tanaman cabai. Tanaman cabai yang diserang lalat buah berdampak pada menurunnya mutu buah cabai. Lalat buah memasukkan telurnya dengan menusukkan ovipositor ke dalam buah dan larvanya akan berkembang di dalam buah. Larva akan merusak daging buah, sehingga buah menjadi busuk dan gugur sebelum mencapai kematangan yang diinginkan (Mardiasih, 2010). Kerugian yang diakibatkan oleh serangan lalat buah pada cabai dapat mencapai 70\% (Sutjipto et al., 2007).

Upaya untuk menanggulangi serangan hama tersebut masih tergantung pada penggunaan pestisida sintetik. Di Indonesia, pestisida sintetik digunakan oleh hampir $80 \%$ petani sayuran untuk mengendalikan serangan organisme pengganggu tanaman. Penggunaan insektisida tersebut jika dilakukan secara terjadwal tanpa memperhatikan kepadatan populasi hama dan dosis terlalu tinggi dapat menimbulkan dampak negatif, seperti timbulnya biotype baru yang resisten terhadap insektisida, serta meninggalkan residu yang berbahaya bagi manusia (Adiyoga dan Soetarso, 1999 dalam Astuti, 2016). Perlu adanya upaya untuk meminimalisir dampak negatif yang diakibatkan oleh pestisida sintetik. Penggunaan bahan alternatif yang ramah lingkungan, seperti penggunaan bahan dari tanaman merupakan salah satu solusi yang dapat dilakukan (Anugraheni, 2018).

Tanaman jarak pagar (Jatropha curcas L.) merupakan salah satu tanaman yang termasuk ke dalam famili Euphorbiaceae. Pada daun dan batang jarak mengandung saponin, flavonoid, tanin, dan senyawa polifenol, sedangkan bijinya mengandung alkaloid, saponin, dan protein beracun yang disebut kursin (Saenong, 2016). Flavonoid merupakan senyawa yang bersifat racun terhadap jenis serangga (Raharjo, 2013). Tanin dapat menghambat masuknya zat makanan ke dalam tubuh serangga, sehingga menyebabkan gangguan metabolisme dan fisiologis sel, dan menyebabkan kerusakan pada sel serangga (Ramayanti et al., 2017). Hodiyah dan Hartini (2014) menyatakan bahwa aplikasi pestisida nabati dari ekstrak daun jarak pagar dengan konsentrasi $20 \mathrm{~mL} \mathrm{~L}^{-1}$ pada cabai umur 7 Minggu Setelah Tanam (MST), menyebabkan tingkat serangan lalat buah sebesar 26,73\%. Berdasarkan uraian diatas, penelitian ini bertujuan untuk mengetahui konsentrasi ekstrak daun jarak pagar yang tepat dalam mengendalikan lalat buah pada cabai.

\section{METODE PENELITIAN}

Penelitian dilaksanakan di Laboratorium Produksi Fakultas Pertanian Universitas Siliwangi Tasikmalaya, dan Laboratorium 
Vapor Heat Treatment (VHT) serta Laboratorium Pestisida Nabati Balai Besar Peramalan Organisme Pengganggu Tumbuhan (BBPOPT) Karawang.

Alat yang digunakan dalam penelitian ini terdiri dari timbangan analitik, blender, erlenmeyer, vacuum drying oven, corong kaca, cawan petri, gelas ukur, tabung reaksi, alumunium foil, lemari es, kain tile, kurungan (ukuran $30 \mathrm{~cm} \times 30 \mathrm{~cm} \times 30 \mathrm{~cm}$ ), gelas plastik, mikroskop, nampan hitam, spatula, hand counter, pinset, kuas kecil No. 1, tisu, kapas, kertas whatman No. 42, toples, alat tulis, label, dan kamera digital.

Bahan yang digunakan dalam penelitian ini terdiri dari imago lalat buah (Bactrocera dorsalis H.), cabai kultivar Tit Segitiga yang sehat dan belum matang berukuran \pm $10 \mathrm{~cm}$ serta bebas dari pestisida sintetik, daun jarak pagar, etil asetat 99.8\%, akuades, yeast, air, gula putih dan tepung kanji.

Rancangan yang digunakan yaitu Rancangan Acak Lengkap (RAL) yang terdiri dari 4 perlakuan dan 6 ulangan sehingga terdapat 24 plot. Perlakuan berupa konsentrasi ekstrak daun jarak pagar yang terdiri atas $\mathrm{A}=$ konsentrasi $0 \%, \mathrm{~B}=$ konsentrasi $0,04 \%, \mathrm{C}=$ konsentrasi $0,08 \%$, $\mathrm{D}=$ konsentrasi $0,16 \%$.

Ekstraksi daun jarak pagar ( $J$. curcas) dilakukan dengan metode maserasi, menggunakan pelarut etil asetat. Sebanyak $100 \mathrm{~g}$ serbuk daun jarak pagar dimasukkan ke dalam blender, kemudian ditambahkan pelarut sebanyak $500 \mathrm{ml}(1: 5 \mathrm{w} / \mathrm{v})$, lalu diblender hingga tercampur. Larutan ekstrak dimasukkan ke dalam erlenmeyer dan ditutup aluminium foil kemudian disimpan selama 24 jam pada suhu kamar. Setelah itu ekstrak hasil maserasi disaring menggunakan kertas whatman No. 42. Ekstrak yang telah disaring kemudian Tabel 1. Tiga senyawa dengan kandungan tertinggi dari ekstrak daun jarak pagar dipekatkan dengan menggunakan vacuum drying oven pada suhu $60{ }^{\circ} \mathrm{C}$ selama 6 jam hingga didapatkan ekstrak kental daun jarak pagar. Ekstrak kental disimpan di dalam lemari es pada suhu $4 \pm 1{ }^{\circ} \mathrm{C}$ sampai digunakan untuk pengujian (Modifikasi dari Rampadarath et al., 2014).

Ekstrak daun jarak pagar diencerkan hingga volume yang diinginkan sesuai dengan konsentrasi, kemudian ditambahkan perekat tepung kanji $10 \%$ sebanyak $0,67 \%$ $(0,67 \mathrm{~mL}$ per $100 \mathrm{~mL}$ air $)$. Cabai dicelupkan pada masing-masing perlakuan ekstrak daun jarak pagar selama 30 detik, sedangkan pada kontrol, cabai hanya dicelupkan pada akuades dengan campuran tepung kanji, kemudian cabai ditiriskan dan dikeringanginkan. Setelah kering, buah cabai dimasukkan ke dalam kurungan dengan cara digantung (Modifikasi dari Miriam, 2013).

Pengujian ini dilakukan dengan uji tanpa pilihan/no choice, sehingga kontrol dan perlakuan berada pada kurungan yang berbeda. Buah cabai yang digunakan sebanyak 10 buah dan serangga uji sebanyak 30 pasang imago B. Dorsalis per kurungan. Pengamatan dilakukan setelah 72 Jam Setelah Aplikasi (JSA).

\section{HASIL DAN PEMBAHASAN}

\section{Analisis senyawa aktif ekstrak daun jarak pagar}

Analisis kandungan senyawa aktif yang terdapat pada daun jarak pagar dengan pelarut metanol, etil asetat dan n-heksan dilakukan dengan menggunakan GC-MS (Gas Chromatography Mass Spectroscopy). Beberapa senyawa aktif yang kandungannya cukup tinggi disajikan dalam Tabel 1 sebagai berikut : 


\begin{tabular}{clll}
\hline No & \multicolumn{1}{c}{ Metanol } & \multicolumn{1}{c}{ Etil asetat } & \multicolumn{1}{c}{ N-heksan } \\
\hline 1 & $\begin{array}{l}\text { Phenol, 2-methyl-5-(1,2,2- } \\
\text { trimethylcyclopentyl)-, (S)- } \\
(73,66 \%)\end{array}$ & Ethylbenzene $(22,61 \%)$ & Phytol $(9,26 \%)$ \\
2 & n-Hexadecanoic acid (7,76\%) & Phytol $(21,89 \%)$ & $\begin{array}{l}\text { Hexadecanoic acid, } \\
\text { methyl ester }(8,01 \%)\end{array}$ \\
3 & $\begin{array}{l}\text { Phenol, 4- } \\
\text { [[(dimethylamino)sulfonyl }] \\
\text { methylamino]- (3\%) }\end{array}$ & p-Xylene (10,13\%) & $\begin{array}{l}\text { Cyclohexene, 1 methyl-4- } \\
(1-\text {-methylethylidene)- } \\
(7,73 \%)\end{array}$ \\
\hline
\end{tabular}

Sumber : Hasil analisis GC-MS

Senyawa yang terkandung pada ekstrak daun jarak pagar dengan pelarut metanol sebagian besar merupakan senyawa phenol. Flavonoid dan tannin merupakan golongan terbesar dari senyawa phenol dengan berat molekul yang tinggi. Flavonoid dan tannin memiliki aktivitas biologi seperti antioksidan, selain itu flavonoid dapat bersifat sebagai antimikroba (Harbone, 1987; Meskin et al., 2002 dalam Nurmillah, 2009).

Kandungan senyawa yang terdapat pada ekstrak daun jarak pagar dengan pelarut etil asetat diantaranya, Ethylbenzene dan pXylene merupakan senyawa kimia yang termasuk pada golongan benzena, sedangkan Phytol termasuk pada golongan terpena. Kandungan senyawa tertinggi yang terdapat pada ekstrak daun jarak pagar dengan pelarut n-heksan termasuk pada golongan lipid, salah satunya yaitu hexadecanoic acid atau asam palmitat.

Pranowo et al (2011) menyatakan bahwa, sebagian besar aktivitas repelensi terhadap spesies-spesies dari ordo Diptera dipengaruhi oleh adanya monoterpena dan seskuiterpena. Meskipun pada umumnya aktivitas repelensi dipengaruhi oleh adanya monoterpena dan seskuiterpena, phytol yang merupakan diterpena juga memiliki aktivitas repelensi terhadap Anopheles gambiae (Odalo et al., 2005).

Hasil GC-MS menunjukkan bahwa senyawa phytol terkandung di dalam ekstrak daun jarak pagar pada pelarut metanol, etil asetat dan n-heksan. Kandungan phytol tertinggi terdapat pada ekstrak daun jarak pagar dengan pelarut etil asetat yaitu sebesar $21,89 \%$, kemudian pada pelarut n-heksan sebesar 9,26\%, dan kandungan senyawa phytol terendah terdapat pada pelarut metanol yaitu sebesar $1,56 \%$.

Hasil uji coba yang telah dilakukan sebelumnya menunjukkan bahwa, dari total 5 buah sampel uji dan 25 pasang imago $B$. dorsalis pada perlakuan ekstrak daun jarak pagar dengan pelarut etil asetat dengan konsentrasi $0,8 \mathrm{~g} \mathrm{~L}^{-1}$ tidak terdapat buah uji yang terserang, sedangkan pada kontrol dan perlakuan ekstrak daun jarak pagar dengan pelarut metanol dan n-heksan terdapat buah uji yang terserang. Maka dari itu, pelarut etil asetat dipilih untuk mengekstraksi daun jarak pagar yang digunakan pada perlakuan untuk pengujian.

\section{Uji hatchability (Daya tetas)}

Uji hatchability (daya tetas) dilakukan dengan tujuan untuk mengetahui kemampuan daya tetas telur dari imago $B$. dorsalis yang digunakan sebagai serangga uji. Lalat buah yang digunakan sebagai serangga uji berumur lebih dari 14 hari sampai dengan 21 hari. Setelah 72 jam telur disimpan, hasil pengamatan menunjukkan bahwa dari 300 butir telur yang dijadikan sampel terdapat 37 butir telur yang belum menetas. Maka dari itu, persentase telur 
yang belum menetas sebesar $12,33 \%$ serta persentase telur yang menetas sebesar $87,67 \%$. Hal ini menunjukkan bahwa serangga uji yang digunakan cocok untuk pengujian karena dapat menghasilkan telur yang mempunyai kualitas bagus, ditandai dengan kemampuan daya tetas telur yang lebih dari $85 \%$.

\section{Intensitas serangan $B$. dorsalis}

Berdasarkan hasil analisis statistik pada Tabel 2, menunjukkan bahwa perlakuan ekstrak daun jarak pagar terhadap intensitas serangan memberikan pengaruh yang tidak nyata terhadap intensitas serangan imago $B$. dorsalis.

Tabel 2. Efikasi ekstrak daun jarak pagar terhadap intensitas serangan B. dorsalis

\begin{tabular}{ccc}
\hline $\begin{array}{c}\text { Konsentrasi ekstrak daun } \\
\text { jarak pagar (w/v) }\end{array}$ & Jumlah buah yang terserang & Intensitas serangan (\%) \\
\hline A $(0 \%)$ & 10 & $100 \quad$ (a) \\
B $(0,04 \%)$ & 10 & $100 \quad$ (a) \\
C $(0,08 \%)$ & 9,67 & 96,67 (a) \\
D $(0,16 \%)$ & 9,83 & 98,33 (a)
\end{tabular}

Keterangan : Nilai rata-rata yang ditandai dengan huruf yang sama berbeda tidak nyata menurut Uji Jarak Berganda Duncan pada taraf nyata 5\%

Hal tersebut diduga karena konsentrasi ekstrak yang digunakan masih terlalu rendah, sehingga bahan aktif yang terkandung di dalam ekstrak juga rendah. Menurut Parijono (1999) dalam Sanjaya et al (2017) menyatakan bahwa ekstrak yang tidak efektif pada konsentrasi rendah mungkin disebabkan karena senyawa yang terkandung di dalamnya kurang efektif atau senyawa tersebut sebenarnya cukup efektif tetapi kandungannya rendah.

Menurut Dumeva et al (2016) dalam Fitri (2017) menyatakan bahwa pemberian konsentrasi ekstrak yang rendah maka pengaruh yang ditimbulkan pada serangga akan rendah juga, sebaliknya pemberian konsentrasi ekstrak yang lebih tinggi maka pengaruh yang ditimbulkan juga tinggi, karena daya kerja suatu senyawa sangat ditentukan oleh besarnya konsentrasi yang diberikan. Konsentrasi ekstrak suatu bahan insektisida dengan pelarut air dikatakan efektif apabila tidak melebihi 10\% (Dadang dan Prijono, 2008).
Hasil penelitian Adebowale dan Adedire (2006) melaporkan bahwa minyak jarak pagar mempunyai efektivitas sebagai antioviposisi hama tanaman kacang tunggak yaitu Callosobruchus maculatus pada konsentrasi $0,5 \%$ sampai $2 \%$ dengan interval $0,5 \%$, jumlah telur yang diletakkan semakin menurun seiring dengan meningkatnya konsentrasi. Astuti et al (2011) melaporkan bahwa pengaruh paparan minyak jarak pagar dengan konsentrasi $0,4 \%$ dan $0,5 \%$ terhadap antioviposisi nyamuk A.albopictus terlihat signifikan, dengan rata-rata jumlah telur yang diletakkan masing-masing sebesar 13,3 dan 16 butir. Pengaruh minyak jarak pagar terhadap kematian larva A. albopictus menunjukkan hasil yang meningkat sesuai dengan konsentrasi aplikasinya, pada konsentrasi tertinggi 0,5\% minyak jarak pagar diperoleh kematian larva sebesar $98,4 \%$.

Adanya hambatan peletakan telur imago lalat buah kemungkinan disebabkan adanya 
senyawa asing pada buah perlakuan yang bersifat penolak, dan atau dapat juga disebabkan karena tertutupnya sinyal penarik yang terdapat pada buah oleh senyawa yang terkandung dalam ekstrak uji (Mardiasih, 2010). Namun dikarenakan konsentrasi ekstrak uji yang digunakan masih rendah, sehingga belum mampu menutupi sinyal senyawa penarik pada buah, dan akhirnya tidak bisa menghambat lalat buah untuk meletakkan telur.

Selain itu, diduga juga karena durasi aplikasi ekstrak yang pendek serta waktu pengujian yang terlalu lama, telah menyebabkan senyawa kimia ekstrak pada buah uji sudah menguap. Pavela (2011) menyatakan bahwa kebanyakan bahanbahan yang bersifat repellent termasuk dalam aromatic hydrocarbon yang mudah menguap di alam dan waktu efisiennya berkurang tergantung pada periode aplikasi dan dosis yang digunakan. Buah cabai memiliki kandungan gizi diantaranya protein, lemak, kalori, kalsium, karbohidrat dan vitamin (A, B1 dan C) yang cukup tinggi sehingga diduga lebih menarik imago $B$. dorsalis untuk datang. Menurut Chinajariwong et al (2003) dalam
Arifiansyah (2012), protein hidrolisat, gula, vitamin $\mathrm{C}$, serta kandungan gizi lainnya merupakan zat yang dibutuhkan oleh imago betina untuk kematangan seksual dan produksi telur, sehingga menjadi penarik yang kuat bagi imago betina $B$. dorsalis.

\section{Jumlah telur yang menetas dan telur yang belum menetas}

Lalat buah mencari makan dan tempat untuk beroviposisi dengan menggunakan indera penciuman dan penglihatan. Lalat buah mengenali lokasi buah melalui bentuk, warna, ukuran, serta tekstur permukaan buah. Imago menusukkan ovipositornya pada permukaan kulit buah dan menyimpan telur di bawah permukaan kulit buah. Tempat peletakkan telur lalat buah ditandai dengan adanya noda atau titik kecil berwarna hitam yang tidak terlalu jelas. Noda-noda kecil bekas tusukan ovipositor ini merupakan gejala awal serangan lalat buah. Telur kemudian menetas dan larva memakan daging buah yang menyebabkan noda-noda kecil berkembang menjadi bercak coklat, kemudian larva akan merusak daging buah sehingga buah menjadi busuk (Ginting, 2009).

Tabel 3. Efikasi ekstrak daun jarak pagar terhadap rata-rata jumlah telur yang menetas dan telur yang belum menetas

\begin{tabular}{ccccc}
\hline $\begin{array}{c}\text { Konsentrasi } \\
\text { ekstrak daun jarak } \\
\text { pagar (w/v) }\end{array}$ & $\begin{array}{c}\text { Jumlah telur } \\
\text { yang menetas } \\
\text { (butir) }\end{array}$ & Hatching (\%) & $\begin{array}{c}\text { Jumlah telur } \\
\text { yang belum } \\
\text { menetas (butir) }\end{array}$ & $\begin{array}{c}\text { Persentase telur } \\
\text { yang belum } \\
\text { menetas (\%) }\end{array}$ \\
\hline A $(0 \%)$ & 108,33 (a) & 93,55 & 7,47 (a) & 6,45 \\
B $(0,04 \%)$ & 94,28 (a) & 89,40 & 11,18 (a) & 10,60 \\
C $(0,08 \%)$ & 121,05 (a) & 94,23 & 7,42 (a) & 5,77 \\
D $(0,16 \%)$ & 101,47 (a) & 91,50 & 9,48 (a) & 8,50 \\
\hline
\end{tabular}

Keterangan : Nilai rata-rata yang ditandai dengan huruf yang sama pada kolom yang sama berbeda tidak nyata menurut Uji Jarak Berganda Duncan pada taraf nyata 5\%

Berdasarkan hasil analisis statistik pada Tabel 3, menunjukkan bahwa perlakuan ekstrak daun jarak pagar dengan berbagai konsentrasi, terhadap rata-rata jumlah telur yang menetas dan telur yang belum menetas menunjukkan hasil yang berpengaruh tidak nyata. Hal ini diduga karena konsentrasi yang digunakan masih rendah, sehingga belum bisa menghambat penetasan telur lalat buah. 
Rata-rata tertinggi jumlah telur lalat buah yang belum menetas terdapat pada konsentrasi $0,04 \%$ sebesar 11,18 butir, sedangkan rata-rata terendah jumlah telur yang belum menetas terdapat pada konsentrasi $0,08 \%$ sebesar 7,42 butir. Lalat buah dapat meletakkan telur sebanyak 40 butir dalam sehari. Telur diletakkan secara berkelompok sebanyak 2 sampai 15 butir. Pada B. dorsalis produksi telur dipengaruhi oleh dua aspek yaitu jumlah ovariole dalam ovarium dan kualitas pakan/tanaman inang saat stadia larva dan imago. Durasi kopulasi akan berpengaruh terhadap jumlah telur yang dihasilkan, namun tidak mempengaruhi penetasan telur (Sayekti, 2104).

Hasil dissecting buah cabai menunjukkan bahwa rata-rata tertinggi jumlah telur yang menetas menjadi larva terdapat pada konsentrasi $0,08 \%$ sebanyak 121,05 ekor, sedangkan rata-rata terendah jumlah telur yang menetas menjadi larva terdapat pada konsentrasi $0,04 \%$ sebanyak 94,28 ekor. Setelah buah cabai dissecting, larva yang terdapat di dalam buah cabai berukuran lebih kecil jika dibandingkan dengan ukuran larva normal. Hal tersebut dikarenakan tingginya populasi larva yang terdapat pada buah cabai hingga mencapai rata-rata lebih dari 90 ekor, sehingga mengakibatkan terjadinya persaingan untuk memenuhi kebutuhan makan.

\section{SIMPULAN}

Berdasarkan hasil penelitian yang telah dilaksanakan, dapat disimpulkan bahwa tidak terdapat konsentrasi ekstrak daun jarak pagar yang tepat dalam mengendalikan lalat buah pada cabai. Hasil analisis GC-MS ekstrak daun jarak pagar dengan menggunakan pelarut metanol, etil asetat dan n-heksan menunjukkan bahwa kandungan terbesar senyawa phytol yang diduga berfungsi sebagai repellent, terdapat pada ekstrak daun jarak pagar dengan pelarut etil asetat yaitu sebesar $21,89 \%$.

\section{UCAPAN TERIMA KASIH}

Ucapan terima kasih disampaikan kepada Lembaga Penelitian dan Pengabdian Masyrakat Universitas Siliwangi yang telah mendanai penelitian ini.

\section{DAFTAR PUSTAKA}

Adebowale, K.O dan Adedire, C.O. 2006. Chemical composition and insectisidal properties of the underutilized Jatropha curcas seed oil. African Journal of Biotechnology. 5(10): 901-906.

Anugraheni, D.D. 2018. Pengaruh Insektisida Nabati Ekstrak Tanaman Kemangi (Ocimum Basilicum) dan Daun Sirih Terhadap Mortalitas Lalat Buah (Bactrocera Sp.). Skripsi. Fakultas Keguruan dan Ilmu Pendidikan Universitas Muhammadiyah Surakarta, Surakarta.

Arifiansyah, R. 2012. Evaluasi Lima Ekstrak Tanaman Sebagai Penolak Lalat Buah Bactrocera sp. (Diptera: Tephritidae) Pada Cabai Merah. Skripsi. Fakultas Pertanian. Institut Pertanian Bogor, Bogor.

Astuti, E.P, A.Riyadhi dan N.R.Ahmadi. 2011. Efektivitas Minyak Jarak Pagar Sebagai Larvasida, Anti-Oviposisi Dan Ovisida Terhadap Larva Nyamuk Aedes albopictus. Buletin Penelitian Tanaman Rempah dan Obat. 22(1): 44-53.

Astuti, R.B. 2016. Pengaruh Pemberian Pestisida Organik Dari Daun Mindi (Melia azedarach L.), Daun Pepaya 
(Carica papaya L.), dan Campuran Daun Pepaya (Carica papaya L.) dan Daun Mindi (Melia azedarach L.) Terhadap Hama dan Penyakit Tanaman Cabai Merah (Capsicum annuum L.). Skripsi. Fakultas Keguruan dan Ilmu Pendidikan Universitas Sanata Dharma, Yogyakarta.

Balai Besar Pengkajian dan Pengembangan Teknologi Pertanian. 2008. Teknologi Budidaya Cabai Merah. Badan Penelitian dan Pengembangan Pertanian, Bogor.

Dadang dan Prijono D. 2008. Insektisida Nabati: Prinsip, Pemanfaatan, dan Pengembangan. Departemen Proteksi Tanaman Institut Pertanian Bogor, Bogor.

Fitri, N.I. 2017. Pengaruh Variasi Konsentrasi Ekstrak Daun Jarak Pagar (Jatropha curcas Linn) Terhadap Mortalitas Larva Aedes aegypti. Skripsi. Fakultas Ilmu Tarbiyah dan Keguruan (FITK) Universitas Islam Negeri (UIN), Mataram.

Ginting, R. 2009. Keanekaragaman Lalat Buah (Diptera: Tephritidae) Di Jakarta, Depok, Dan Bogor Sebagai Bahan Kajian Penyusunan Analisis Risiko Hama. Tesis. Institut Pertanian Bogor, Bogor.

Hodiyah, I dan E. Hartini. 2014. Efikasi Beberapa Bahan Pestisida Nabati dalam Pengendalian Hama Tanaman Cabai. Jurnal Agroekoteknologi. 06(02): $95-104$.

Mardiasih, W.P. 2010. Aktivitas Insektisida Dan Penghambat Peneluran Ekstrak Cerbera odollam Dan Cymbopogon citratus Terhadap Lalat Buah (Bactrocera carambolae) Pada Belimbing. Tesis. Sekolah Pasca Sarjana Institut Pertanian Bogor, Bogor.
Miriam, D.R. 2013. Minyak Nilam Sebagai Biofungisida Untuk Mengendalikan Penyakit Antraknosa (Colletotrichum capsici (Syd.) Butler \& Bisby) Pada Buah Cabai. Skripsi. Fakultas Pertanian Institut Pertanian Bogor, Bogor.

Nurmillah, O.Y. 2009. Kajian Aktivitas Antioksidan dan Antimikroba Ekstrak Biji, Kulit Buah, Batang, dan Daun Tanaman Jarak Pagar (Jatropha curcas L.). Skripsi. Fakultas Teknologi Pertanian Institut Pertanian Bogor, Bogor.

Odalo, J.O., Omolo, M.O., Malebo, H., Angira, J., Njeru, P.M., Ndiege, I.O., Hassanali, A. 2005. Repellency of essential oils of some plants from the Kenyan coast against Anopheles gambiae. Acta Tropica. 95 : 210-218.

Pavela, R. 2011. Natural Products as Allelochemicals in Pest Management. In: Natural Products in Plant Pest Management. CAB International, UK. 134-148.

Pranowo, D, T.Apriyono, T.D.Wahyuningsih, dan Suputa. 2011. Pemanfaatan Ekstrak Daun Tembakau Dan Daun Selasih Sebagai Insect Ovipositing Repellent Terhadap Lalat Buah Bactrocera carambolae. Seminar Nasional Kimia dan Pendidikan Kimia III (SNKPK III), Yogyakarta.

Raharjo, T.J. 2013. Kimia Hasil Alam. Yogyakarta: Pustaka Pelajar.

Ramayanti, I, L. Kamalia, dan P.P. Utami. 2017. Efektivitas Ekstrak Daun Kemangi (Ocimum basilicum) sebagai Bioinsektisida Sediaan Antinyamuk Bakar Terhadap Kematian Nyamuk Aides aegypti. Journal of Agromedicine and Medical Sciences. 3(2): 6-10. 
Rampadarath, S, D.Puchooa dan M.R.Sanmukhiya. 2014. Antimicrobial, Phytochemical and Insecticidal Properties of Jatropha Spesies and Wild Ricinus communis L. Found in Mauritius. International Journal of Pharmacognosy and Phytochemical Research. 6(4): 831840.

Saenong, M.S. 2016. Tumbuhan Indonesia Potensial Sebagai Insetisida Nabati Untuk Mengendalikan Hama Kumbang Bubuk Jagung (Sitophilus spp.). Jurnal Litbang Pertanian. 35(3): 131-142.

Sanjaya, A.A, A. Yaku dan L.E. Lindongi. 2017. Penggunaan Ekstrak Daun Sirsak, Daun Babadotan, Serai, Daun Pepaya, dan Buah Mengkudu Sebagai Insektisida Nabati Dalam Pengendalikan Plutella xylostella (Lepidoptera: Plutellidae) Pada Tanaman Sawi. Jurnal Agrotek. 5(6): 55 .
Sayekti, E. 2014. Kelulushidupan, Lama Perkembangan dan Kematangan Seksual Empat Spesies Lalat Buah (Bactrocera papayae, Bactrocera carambolae, Bactrocera cucurbitae, dan Bactrocera albistrigata) Di Laboratorium. Skripsi. Fakultas Pertanian Universitas Padjadjaran, Bandung.

Sutjipto, S. Prastowo dan M.W. Jadmiko. 2007. Keandalan Ekstrak Daun Selasih Sebagai Insektisida Nabati Untuk Pengendalian Lalat Buah Pada Cabai Merah. Laporan Penelitian Hibah Bersaing. Fakultas Pertanian Universitas Jember, Jember. 